\title{
Isolasi dan Identifikasi Khamir Selulolitik Dari Tanah Rizosfer Anggrek Puser Bumi (Pecteilis susannae L.) di Hutan Wonosadi Gunung Kidul DIY
}

\author{
LADY DIANA $^{1}$, TITI LASMINI ${ }^{2}$ \\ ${ }^{1}$ Stasiun Karantina Pertanian Kelas 1 Entikong \\ Jl. Lintas Malindo No. 22-23 Entikong, Sanggau, Kalimantan Barat 78557 \\ email: ladydiana3487@yahoo.co.id \\ ${ }^{2}$ Akademi Kesehatan John Paul II Pekanbaru \\ Jl. Permata I No. 32, Labuh Baru Barat, Payung Sekaki, Pekanbaru 28292 \\ email: lasmini.titi@gmail.com
}

\begin{abstract}
P. susannae (L.) Raf. is terrestrial orchid grown on the floor of Wonosadi forest. They belong to endangered species of orchid. Those orchids have grown well on degraded leaf litter and surround the grass. So, these plant were interesting to be elucidated especially for their nutrient availability. The was investigate the possibility of yeast associated with terrestrial orchids and cooperate in the provision of nutrients. The research objective was to obtain cellulolytic yeast on soil of root system $P$. susannae (L.) Raf. The research began with rhizosphere soil sampling on orchids root system P. susannae (L.) Raf. in two place in Forest Wonosadi. Soil samples were analyzed in the laboratory of microbiology, including the determination of the population of cellulolytic yeast and yeast isolated from soil of root system $P$. susannae (L.). directly from root system using Carboxy methyl cellulose medium (CMC), incubated for 5 days. Colonies were counted for the determination of population growth. Yeast colonies were grown separately isolated as a single culture. Sorting trough growth experiments using a form of cellulose (cellulose microcrystalline, leaf litter and paper) was different. Isolates were grown on microcrystalline cellulose selected for further testing based on the ability to use CMC. Activity was determined by the use of cellulose determine reducing sugar levels (glucose) was released using a spectrophotometer (OD $540 \mathrm{~nm}$ ). The results showed that the rhizosphere soil P. susannae (L.) Raf. containing a yeast population $\left(17 \times 10^{2} \mathrm{CFU}\right.$ and $\left.2.3 \times 10^{2} \mathrm{CFU}\right)$ and was dominated by the four isolates (K2, K16, A9 and A10) cellulolytic yeasts. The results of the identification of the four isolated of yeasts like Saccharomyces sp. (K2) and Candida sp. (K16, A9 and A10).
\end{abstract}

Keywords: Candida sp., cellulose microcrystalline, cellulolytic yeast, Pecteilis susannae L., Saccharomyces sp.

\section{INTISARI}

Penelitian ini berusaha menyelidiki salah satu kelompok fungi tanah, terutama khamir yang berasosiasi dengan sistem perakaran anggrek tanah $\left(P\right.$. susannae $\left.\left(L_{.}\right)\right)$yang digunakan sebagai objek penelitian ini. Anggrek tersebut memiliki bunga yang indah, mempunyai habitat yang spesifik dan paling banyak terdapat di Hutan Wonosadi. Kespesifikan anggrek tersebut kemungkinan terkait dengan ketersediaan nutrient khusus yang merupakan kerjasama dengan mikrobia tanah. Mikrobia khususnya khamir banyak terdapat pada rizosfer tanaman anggrek yang belum diketahui dengan pasti peranannya. Beberapa jenis khamir tanah bersifat selulolitik yang mempunyai arti penting dalam pengadaan nutrient tertentu bagi anggrek tersebut. Tujuan penelitian adalah untuk mendapatkan khamir selulolitik dan menganalisis aktivitas degradasi selulosa oleh khamir tanah rizosfer anggrek P. susannae (L.) di dua lokasi Hutan Wonosadi. Sampel tanah dianalisis secara mikrobiologi di Laboratorium. Isolasi khamir selulolitik dilakukan menggunakan media chytophaga (CMC agar). Isolat khamir diseleksi secara kuantitatif berdasarkan kemampuan tumbuh pada beberapa bentuk selulosa (Cellulose Microcrystalline, seresah daun dan kertas). Aktivitas degradasi selulosa oleh isolat terpilih dilakukan dengan menumbuhkan pada media chytophaga liquid. Isolat 
terpilih diidentifikasi berdasarkan karakter morfologi dan karakter fisiologi dan biokimia. Hasil penelitian menunjukkan bahwa didapatkan empat khamir selulolitik yaitu isolat K2, K16, A9 dan A10. Berdasarkan pengamatan morfologi, uji karakter fisiologi dan biokimia yang dilakukan khamir selulolitik tersebut diduga merupakan anggota dari genus Saccharomyces sp. (isolat K2) dan Candida sp. (isolat K16, A9 dan A10).

Kata kunci: Candida sp., cellulose microcrystalline, khamir selulolitik, Pecteilis susannae L., Saccharomyces sp.

\section{PENDAHULUAN}

Khamir adalah fungi uniseluler dan tersebar luas di berbagai lingkungan, yaitu akuatik, terrestrial, maupun di atmosfer (Hong et al., 2002). Khamir mampu berasosiasi dengan tumbuhan tanpa menyebabkan kerusakan ataupun penyakit (Abdel-Motaal et al., 2009). Bentuk asosiasi dengan tumbuhan berfungsi sebagai agen biokontrol (memiliki potensi aktivasi antifungi) terhadap fungi patogen (El-Tarabily et al., 2006). Penelitian yang dilakukan Kanti (2007) pada tanah kebun Biologi Wamena mengungkapkan bahwa jenis khamir anggota genus Cryptococcus berperan dalam metabolisme selulosa karena mampu menghasilkan enzim $\beta$-glikosidase yaitu enzim yang mengkatalisis proses degradasi selulosa. Selulosa dalam tanah berasal dari perombakan material tumbuhan dan sebagian kecil berasal dari perombakan jamur dan bakteri di dalam tanah (Sukumaran et al., 2005).

Salah satu tumbuhan yang diduga berasosiasi dengan khamir adalah anggrek Pecteilis susannae (L.) Raf. Anggrek jenis ini banyak ditemukan di hutan Wonosadi. Penelitian tentang mikroorganisme yang berasosiasi dengan tanaman $P$. susannae (L.) Raf. saat ini masih sangat terbatas. Oleh karena itu maka dilakukan penelitian tentang khamir yang memiliki kemampuan mendegradasi selulosa pada daerah rizosfer tanaman anggrek Pecteilis susannae (L.) Raf. Hutan Wonosadi yang terletak di Dusun Duren, Desa Beji, Kecamatan Ngawen, Kabupaten Gunung Kidul, Daerah Istimewa Yogyakarta.

\section{METODE}

Isolasi khamir. Isolasi khamir dari tanah rizosfer dilakukan dengan cara mengambil tanah rizosfer (yang menempel pada akar s/d jarak $5 \mathrm{~mm}$ dari permukaan akar (rizoplan) kemudian tanah ditimbang 10 gram yang disuspensikann ke dalam $90 \mathrm{ml}$ akuades steril. Selanjutnya diinokulasikan secara spread plate sebanyak $0,1 \mathrm{ml}$ ke permukaan media YM (Yeast extract - Malt extract) Agar dengan komposisi (g/l) : 3-yeast extract, 3malt extract, 5-pepton, 10-glukosa, 20-bacto agar dan 0,1-chloramphenicol dalam $1000 \mathrm{ml}$ akuades. Diinkubasi pada suhu ruang selama 5 hari. Khamir yang tumbuh pada media YMA selanjutnya dipurifikasi pada media YMA yang baru. Pemisahan koloni dilakukan 2 kali, sehingga diperoleh tingkat kemurnian yang tinggi (Kanti, 2007). Isolat murni yang telah diperoleh dipindah ke media YMA pada tabung reaksi.

Seleksi khamir selulolitik. Seleksi khamir dilakukan dengan menggunakan media selulosa Carboxy Methyl Cellulose (CMC) dengan komposisi (g/l) : 1- $\left.\mathrm{NH}_{4}\right) 2 \mathrm{SO}_{4}$, 1- $\mathrm{MgSO}_{4}, \quad 1-\mathrm{MnSO}_{4}$, 1-glukosa, 1-yeast extract, $1-\mathrm{FeCl}_{3}$ dan 10-CMC, 20-bacto agar, dalam $1000 \mathrm{ml}$ akuades. Semua isolat murni yang didapatkan dari proses purifikasi ditumbuhkan pada media tersebut, selanjutnya diinkubasi pada suhu $30^{\circ} \mathrm{C}$ selama 5 hari. Untuk mengetahui adanya aktivitas selulase maka pada akhir inkubasi isolat dalam media yang mengandungg CMC diberi $0,1 \%$ congored selama 20 menit pada suhu ruang, kemudian bilas dengan $1 \mathrm{M} \mathrm{NaCl}$ selama 15 menit. Indikasi adanya selulolitik organisme adalah terbentuknya zona bening di sekitar koloni yang tumbuh. Kemampuan selulolitiknya dapat ditentukan dengan cara menghitung rasio antara luas zona bening yang terbentuk dengan luas koloni. Strain yang memiliki kapasitas selulolitik kemudian ditumbuhkan pada medium likuid untuk 
menentukan aktivitas degradasi selulosa. Aktivitas degradasi selulosa masing-masing kultur diukur dengan menentukan gula reduksi (Sumira et al., 2011; Kanti, 2007).

Uji kemampuan tumbuh pada bentuk selulosa berbeda. Isolat khamir yang telah terseleksi selanjutnya diuji kemampuannya mendegradasi selulosa murni dengan cara menginokulasikan isolat tersebut pada medium yang mengandung selulosa berbeda yaitu Cellulose microcrystalline, seresah daun dan kertas. Komposisi medium tersebut adalah $(\mathrm{g} / \mathrm{l}): 0,8-\mathrm{KH}_{2} \mathrm{PO}_{4}, 0,2-\mathrm{KH}_{2} \mathrm{PO}_{4}, 0,2-$ $\mathrm{MgSO}_{4}, \quad 0,2-\mathrm{NaCl}, 1-\mathrm{NaNO}_{3}, 0,01-\mathrm{CaCO}_{3}$, 10- selulosa, 20-bacteriological agar dalam $1000 \mathrm{ml}$ akuades. Medium disterilisasi pada suhu $121^{\circ} \mathrm{C}$ selama 15 menit. Isolat diinokulasikan dan dibiarkan selama 4 hari pada suhu ruang. Untuk mengetahui adanya aktivitas selulase maka pada akhir inkubasi isolat dalam selulosa diberi $0,1 \%$ congored selama 20 menit pada suhu ruang, kemudian dibilas dengan $1 \mathrm{M} \mathrm{NaCl}$ selama 15 menit. Indikasi aktivitas selulolitik organisme adalah terbentuknya zona bening di sekitar koloni yang tumbuh. Kemampuan selulolitiknya dapat ditentukan dengan cara menghitung rasio antara luas zona bening yang terbentuk dengan luas koloni.

\section{Uji pertumbuhan dan aktivitas} degradasi selulosa. Pengujian aktivitas degradasi selulosa didasarkan pada mendegradasi selulosa oleh strain khamir menjadi gula reduksi. Untuk menentukan aktivitas degradasi selulosa terlebih dahulu dilakukan persiapan kultur pada media cair CMC dengan cara isolat murni diinokulasikan sebanyak 1 ose ke dalam $5 \mathrm{ml}$ media CMC cair dengan komposisi (g/l): $1\left(\mathrm{NH}_{4}\right)_{2} \mathrm{SO}_{4}, 1$ $\mathrm{MgSO}_{4}, \quad 1$ - $\mathrm{MnSO}_{4}$, 1-glukosa, 1-yeast extract, $1 \mathrm{FeCl}_{3}$ dan 10-CMC dalam $1000 \mathrm{ml}$ akuades dan diinkubasi dengan suhu $30^{\circ} \mathrm{C}$ pada rotary shaker dengan kecepatan $100 \mathrm{rpm}$ selama 3 hari (Kanti, 2007; Samira et al., 2011). Setelah itu sampel dimasukkan ke dalam $30 \mathrm{ml}$ media CMC cair sebanyak 5$10 \%$ dan diinkubasi pada suhu $30^{\circ} \mathrm{C}$ pada rotary shaker dengan kecepatan $100 \mathrm{rpm}$ selama 4 hari. Selanjutnya pengujian aktivitas degradasi selulosa dilakukan setiap hari dengan cara sebagai berikut: sebanyak $2 \mathrm{ml}$ kultur cair diambil dari medium lalu disentrifugasi pada $6000 \mathrm{rpm}, 4^{\circ} \mathrm{C}$ selama 15 menit, $1 \mathrm{ml}$ supernatan dari sampel ditambahkan $1 \mathrm{ml}$ substrat (CMC $1 \%$ ) kemudian diinkubasikan pada $37^{\circ} \mathrm{C}$ selama 2 jam. Setelah diinkubasi reaksi dihentikan dengan menambahkan $3 \mathrm{ml}$ reagen DNS, kemudian dipanaskan pada air mendidih selama 7 menit lalu didinginkan pada air mengalir. Densitas optisnya diukur pada 540 nm. Konsentrasi glukosa ditentukan dengan kalibrasi kurva standar glukosa. Selain itu dilakukan juga pengukuran terhadap biomassa khamir dengan cara kultur cair diambil dari medium penghasil selulase sebanyak $1 \mathrm{ml}$ kemudian diukur dengan spektrofotometer pada OD $600 \mathrm{~nm}$ (Kanti, 2007).

Identifikasi khamir. Identifikasi berdasarkan morfologi koloni dan morfologi sel dilakukan pada isolat terpilih yaitu isolat yang dapat menggunakan CMC pada tahap isolasi. Pengamatan morfologi meliputi: morfologi koloni (warna, bentuk koloni, tepi dan elevasi koloni) dan morfologi sel (bentuk sel, membentuk pseudo hifa atau true hifa, reproduksi vegetatif (budding, fission, konidia) dan reproduksi seksual (bentuk spora: askospora dan basidiospora).

Identifikasi berdasarkan karakter fisiologi dan biokimia meliputi uji urease, uji fermentasi karbon, uji asimilasi karbon, uji asimilasi nitrogen, uji pertumbuhan pada temperatur, uji pertumbuhan pada glukosa, uji pertumbuhan pada $1 \%(\mathrm{v} / \mathrm{v})$ asam asetat dan uji produksi asam. Identifikasi isolat khamir yang berhasil diisolasi dari daerah rizosfer tanaman anggrek $P$. susannae (L.) Raf. diidentifikasi menggunakan buku "Yeast: Characteristic and Identification" yang merupakan kunci identifikasi dari Barnet, Payne dan Yarrow (2000).

Klasifikasi Fenotipik dengan Metode Numerical Taxonomy. Metode klasifikasi numerik bertujuan menggolongkan setiap strain mikrobia ke dalam kelompok takson yang homogeny berdasarkan sejumlah besar data fenotopik kemudian menggunakan hasil klasifikasi tersebut sebagai dasar untuk menghasilkan sistem identifikasi yang lebih 
baik. Langkah kerja klasifikasi adalah sebagai berikut: koleksi data, pemasukkan unit data karakter ke dalam matriks nxt, preparasi data dalam matriks nxt dengan program $P F E$ (Programmer File Editor), analisis data dengan MVSP (Multivariate Statistical Package) Version 3,1 A untuk mengkonstruksi matriks similaritas dan dendogram. Algoritma pengklasteran (Clustering) menggunakan Average linkage atau UPGMA (Unweighted Pair Group Method with Aritmetic Average) dan mengedit dendogram dengan program Paintshop Pro (Sembiring, 2002).

\section{HASIL}

Isolat Khamir Selulolitik. Dari hasil isolasi pada medium YMA diperoleh 29 isolat khamir murni dengan kepadatan populasi (CFU/gram) pada lokasi I dan II secara berturut-turut yaitu 17x102 CFU/gram dan 2,3×102 CFU/gram. Hasil seleksi menggunakan medium selulosa mendapatkan 10 isolat khamir. Dari 10 isolat yang terseleksi, isolat K16 memiliki kemampuan selulolitik tertinggi dibandingkan dengan isolat lain, dengan kemampuan degradasi selulosa 9,640.

Kemampuan tumbuh pada Cellulose Microcrystaline. Diperoleh 4 isolat khamir yang tumbuh pada cellulose microcrystalline yaitu K2, K16, A9 dan A10. Dengan kemampuan selulolitik masing-masing adalah 1,39, 1,79, 1,42 dan 1,80.

Pertumbuhan dan aktivitas degradasi selulosa. Khamir diketahui mampu memetabolisme selulosa sebagai sumber energi yang digunakan untuk membentuk komponen sel yang dibutuhkan (Sukumaran et al., 2005).

Tabel 1. Hasil seleksi kemampuan isolat pendegradasi CMC berdasarkan luas zona jernih yang terbentuk

\begin{tabular}{lcccc}
\hline No. & $\begin{array}{c}\text { Kode } \\
\text { isolat }\end{array}$ & $\begin{array}{c}\text { Luas koloni } \\
\left(\mathrm{cm}^{2}\right)\end{array}$ & $\begin{array}{c}\text { Luas zona jernih } \\
\left(\mathrm{cm}^{2}\right)\end{array}$ & $\begin{array}{c}\text { Kemampuan selulolitik } \\
\text { (luas zona jernih : luas koloni) }\end{array}$ \\
\hline 1. & $\mathrm{~K} 2$ & 0,491 & 0,961 & 1,955 \\
\hline 2. & $\mathrm{~K} 5$ & 0,963 & 1,250 & 1,298 \\
\hline 3. & $\mathrm{~K} 9$ & 0,177 & 0,491 & 2,813 \\
\hline 4. & $\mathrm{~K} 16$ & 0,165 & 1,591 & 9,640 \\
\hline 5. & $\mathrm{~A} 1$ & 0,491 & 0,707 & 1,440 \\
\hline 6. & $\mathrm{~A} 3$ & 0,707 & 1,257 & 1,778 \\
\hline 7. & $\mathrm{~A} 6$ & 0,707 & 1,964 & 2,778 \\
\hline 8. & $\mathrm{~A} 8$ & 0,491 & 0,707 & 1,440 \\
\hline 9. & $\mathrm{~A} 9$ & 0,962 & 2,378 & 4,843 \\
\hline 10. & A10 & 0,491 & 4,420 & 9,002 \\
\hline
\end{tabular}

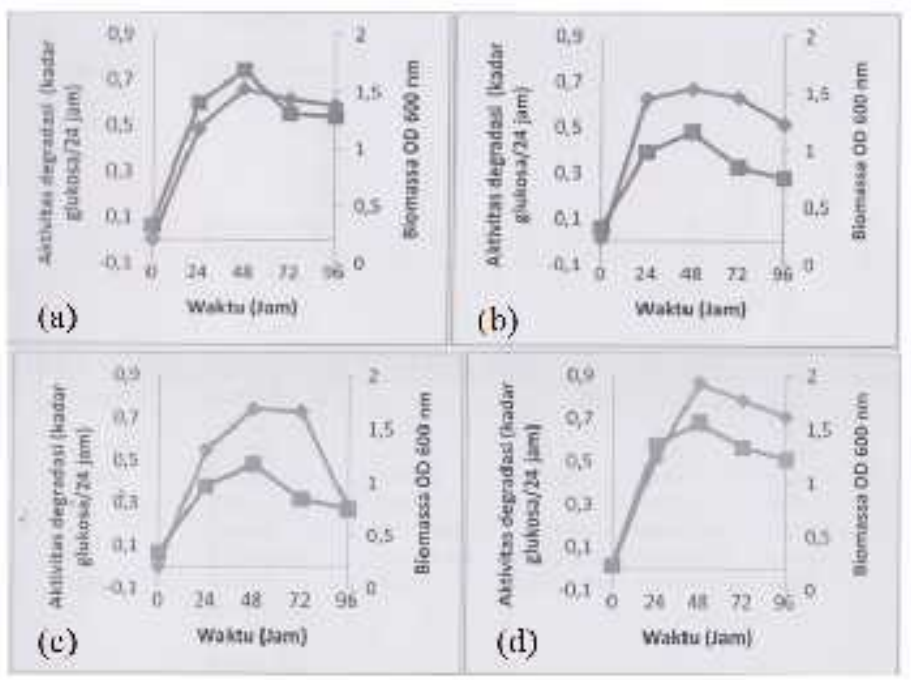

Gambar 1. Pertumbuhan dan aktivitas degradasi selulosa isolat khamir selulolitik: isolat K2 (a), isolat K16 (b), isolat A9 (c), isolat A10 (d) ( $\bullet=$ aktivitas degradasi selulosa; $=$ pertumbuhan). 
Berdasarkan data yang dijelaskan oleh Gambar 1. terlihat bahwa aktivitas degradasi selulosa yang dihasilkan oleh masing-masing isolat khamir digunakan sebagai sumber energi dalam metabolisme mereka. Aktivitas degradasi selulosa isolat khamir selulolitik dipengaruhi oleh kadar glukosa di dalam kultur. Ketika sel diinokulasikan ke media yang mengandung selulosa maka sel akan terpacu memproduksi enzim yang diperlukan

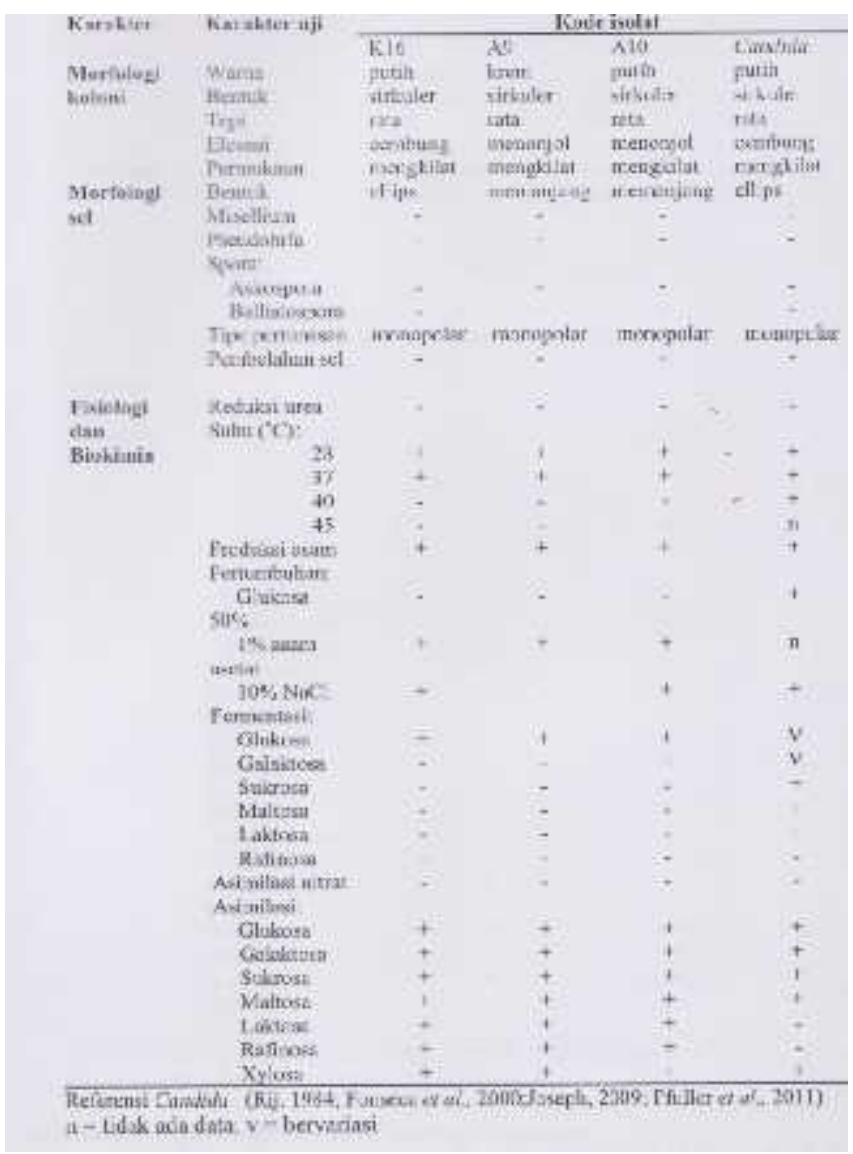

untuk mendegradasi selulosa menjadi glukosa.

Karakteristik Khamir. Isolat khamir yang telah berhasil diisolasi sebagai khamir selulolitik diidentifikasi berdasarkan karakter morfologi dan fisiologi dan biokimia. Berdasarkan karakteristik tersebut (Gambar 2) maka isolat yang diteliti memiliki kemiripan dengan anggota dari genus Saccharomyces sp. (K2) dan Candida sp. (K16, A9 dan A10).

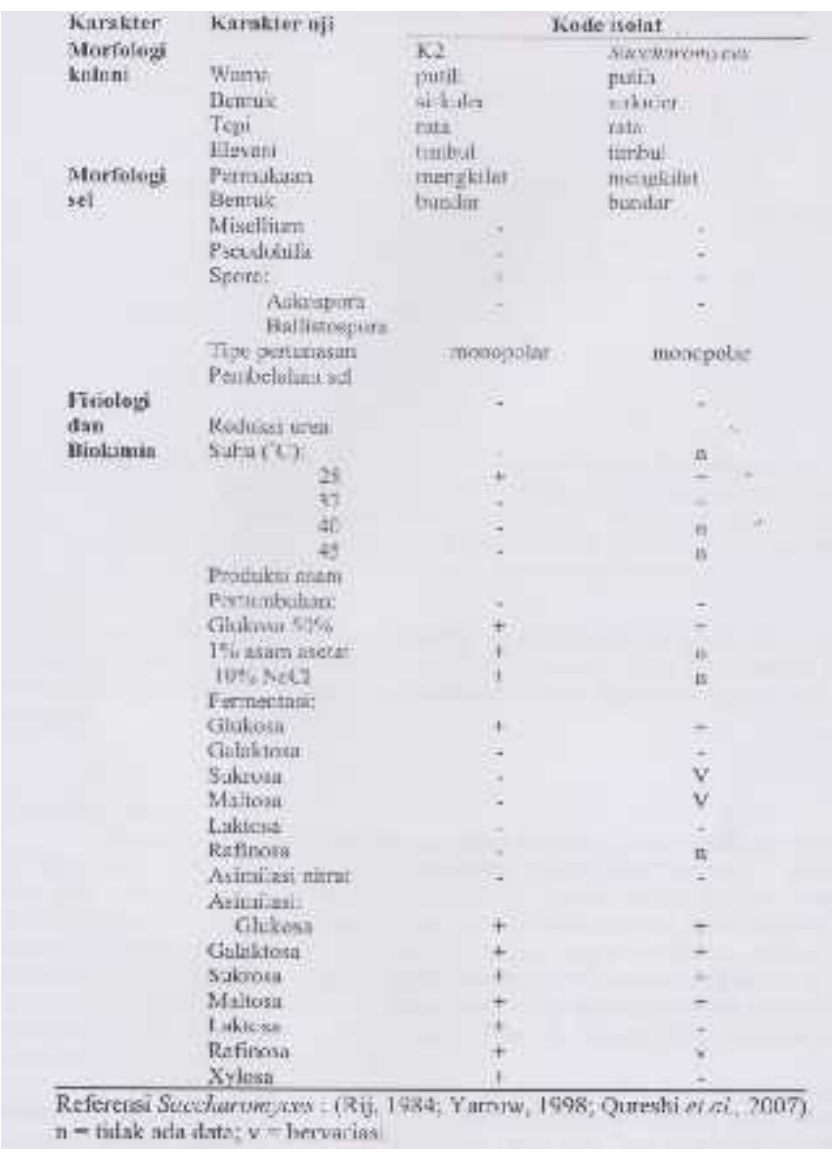

Gambar 2. Karakter yang digunakan dalam identifikasi khamir selulolitik

Analisis Fenotipik dengan Metode Numerical Taxonomy. Metode klasifikasi fenotipik dengan metode Numerical taxonomy bertujuan mengelompokkan mikrobia ke dalam kelompok takson berdasarkan sejumlah data fenotipik sebagai dasar untuk menghasilkan sistem identifikasi yang lebih baik (Sembiring, 2004). Semua genus dalam kluster memiliki tingkat similaritas di atas $70 \%$ (distance level). Secara keseluruhan isolat yang ada memiliki similaritas yang cukup tinggi yaitu di atas $70 \%$. Hal ini dikarenakan keterbatasan karakteristik yang digunakan dalam identifikasi isolat tersebut. 


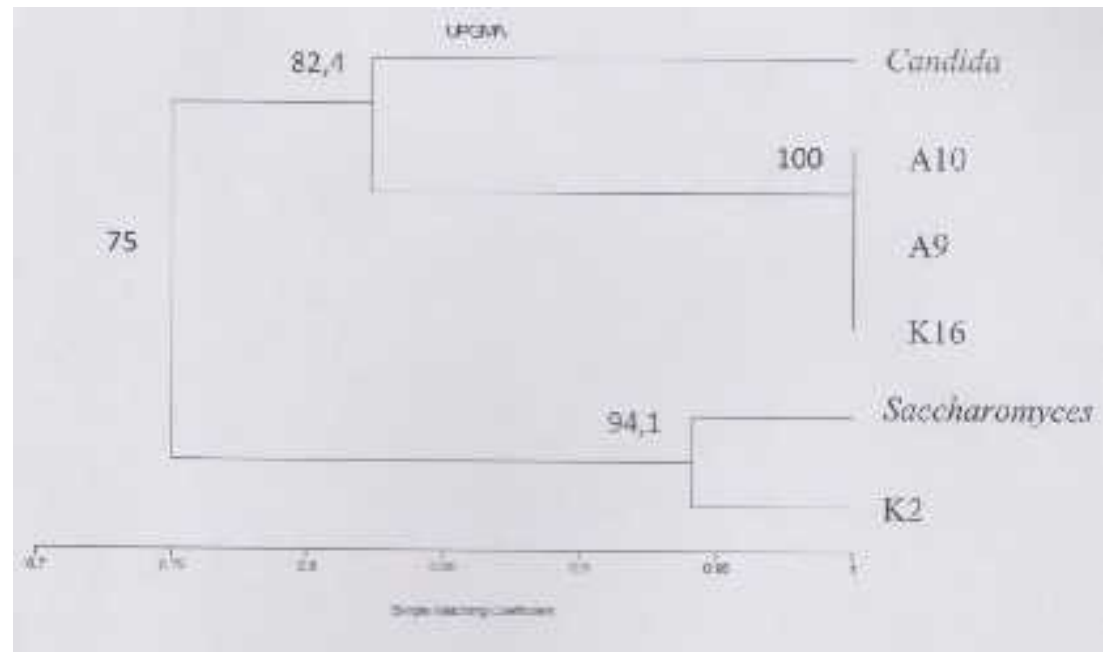

Gambar 3. Hubungan kemiripan antar isolat khamir selulolitik dibandingkan dengan Candida dan Saccharomyces (Qureshi et al., 2007; Fonseca et al., 2000; Joseph, 2009; Pfuller et al., 2011) berdasarkan indeks similaritas menggunakan Simple Matching Coefficient (SSM) dengan algoritma UPGMA (Unweighted Pair Group Method with Aritmetic Average).

\section{PEMBAHASAN}

Khamir selulolitik adalah khamir yang memiliki kemampuan mensintesis enzim selulase yang berguna dalam proses degradasi bahan-bahan selulosik. Enzim selulase menghidrolisis selulosa dan menghasilkan produk primer berupa glukosa, selobiosa dan oligosakarida. Khamir berasosiasi dengan tumbuhan dengan cara mengkolonisasi akar tanaman. Khamir membantu penyediaan nutrien bagi inang dan inang akan mengeluarkan eksudat yang berguna bagi khamir untuk proses metabolismenya (AbdelMotaal et al., 2009). Asosiasi khamir dengan tumbuhan dipengaruhi oleh kondisi lingkungan, sehingga dalam satu jenis tumbuhan yang sama di tempat yang berbeda belum tentu berasosiais dengan jenis khamir yang sama.

Di sekitar tempat tumbuh anggrek Pecteilis susannae (L.) Raf. banyak terdapat seresah daun, rerumputan yang telah kering dan ranting-ranting kecil yang gugur. Seresah daun, rerumputan kering dan ranting-ranting tersebut secara alami akan hancur karena proses pelapukan yang dipengaruhi berbagai faktor lingkungan. Proses pelapukan sisa-sisa tumbuhan tersebut juga dilakukan oleh organisme tanah baik hewan kecil seperti cacing tanah maupun mikrobia yang hidup di tanah yaitu dari kelompok bakteri, khamir dan fungi. Kelompok mikrobia tersebut banyak ditemukan hidup di area rizosfer sistem perakaran tanaman yang memiliki ketebalan beberapa mm dari permukaan akar.

Khamir yang berhasil diisolasi sebanyak 29 isolat. Jenis mikroorganisme yang berbeda dikarenakan perbedaan senyawa eksudat yang dikeluarkan melalui akar tanaman. Hidup suatu organisme di daerah rizosfer tergantung pada keberlangsungan nutrisi yang dibutuhkannya dari tanaman (Walker et al., 2003). Populasi khamir yang berhasil didapatkan berdasarkan jumlah koloni (CFU/gram) pada lokasi I dan II berturut-turut yaitu $17 \times 10^{2} \mathrm{CFU} / \mathrm{gram}$ dan $2,3 \times 10^{2}$ CFU/gram.

Berdasarkan hasil yang diperoleh diketahui bahwa 4 isolat bersifat selulolitik memiliki enzim yang bersifat aktivator dalam reaksi biokimia dan bersifat spesifik terhadap substrat sehingga mempermudah pemutusan suatu rantai tertentu (Syamsudin et al., 2008). Keempat isolat khamir tersebut memiliki kemampuan untuk menggunakan selulosa sebagai sumber karbon. Kemampuan selulolitik tertinggi ditunjukkan oleh isolat A10 dan terendah ditunjukkan oleh isolat K2. Khamir selulolitik menghasilkan enzim selulase yang menghidrolisis selulosa dan menghasilkan produk primer berupa glukosa (Sukumaran et al., 2005). 
Khamir menghidrolisis selulosa menjadi glukosa, senyawa yang lebih sederhana agar dapat dengan mudah diabsorbsi oleh sel mereka. Glukosa berguna sebagai sumber energi yang digunakan untuk membentuk komponen sel yang dibutuhkan oleh khamir (Sukumaran et al., 2005). Pertumbuhan biomassa sel khamir pada Gambar 1. menunjukkan bahwa khamir menggunakan glukosa yang dihasilkan dari proses hidrolisis untuk pertumbuhan mereka. Produksi enzim selulase diinduksi oleh keberadaan substrat (Chawla et al., 2009). Keberadaan senyawa organik dan jumlah biomassa khamir sangat mempengaruhi proses degradasi selulosa (Gambar 1.) Kedua faktor tersebut memegang peranan penting dalam menentukan aktivitas degradasi selulosa. Pertumbuhan biomassa sel ditentukan oleh keberadaan substrat yang mudah terabsorbsi ke dalam sel.

Isolat khamir selulolitik yang berhasil diperoleh dari tanah rizosfer anggrek $P$. susannae (L.) Raf. masing-masing memiliki karakteristik yang berbeda, baik karakteristik morfologi maupun sifat fisiologi dan biokimianya. Keempat genus yang diduga sebagai Saccharomyces sp. dan Candida sp. merupakan genus khamir yang umum ditemukan di tanah (Kanti, 2007; Kanti dan Sudiana, 2002). Selain memiliki kemampuan untuk menghidrolisis selulosa isolat $\mathrm{K} 2$ (Saccharomyces sp.) yang diisolasi dari rizosfer anggrek $P$. susannae (L.) Raf. ternyata juga memiliki kemampuan untuk menghasilkan indole-3-acetic-acid (IAA) (Lasmini dan Soetarto, 2014).

Metode klasifikasi fenotipik dengan metode numerical taxonomy bertujuan mengelompokkan mikrobia ke dalam kelompok takson berdasarkan sejumlah data fenotipik sebagai dasar untuk menghasilkan sistem identifikasi yang lebih baik (Sembiring, 2004). Similaritas fenotopik yang ditunjukkan oleh Candida sp. dan Saccharomyces sp. dapat dibedakan karakteristiknya dalam uji fisiologi dan biokimia yang meliputi reaksi asimilasi, fermentasi dan pertumbuhan pada temperatur tertentu. Keduanya berbeda dalam hal reproduksi seksualnya. Candida sp. tidak ditemukan memiliki askospora, sementara Saccharomyces ditemukan memiliki askospora berbentuk spheroidal. Secara keseluruhan isolat yang ada memiliki similaritas yang cukup tinggi yaitu di atas 70\%. Hal ini dikarenakan keterbatasan karakteristik yang digunakan dalam identifikasi isolat tersebut. Klasifikasi dengan metode numerical taxonomy, suatu spesies jika terdapat dalam kluster yang sama dengan tingkat similaritas $70 \%$ atau lebih ditentukan sebagai genus yang sama (Champbell, 1972; Sneath et al., 1986). Kenampakkan morfologi suatu isolat khamir dalam satu spesies dapat berbeda karena perubahan lingkungannya, namun tidak secara genetik. Dinamika lingkungan lebih cepat mempengaruhi perubahan morfologi dan fisiolgi mikroorganisme dibandingkan dengan perubahan secara genetik. Perubahan secara genetik terjadi dalam kurun waktu yang sangat lama dalam satu periode evolusi, komposisi DNA-nya cenderung stabil.

Komposisi dalam sebuah kluster tergantung pada kriteria yang digunakan untuk menentukan genus. Perbedaan yang muncul pada dendogram mengindikasikan bahwa harus hati-hati dalam menentukan interpretasi hubungan antar genus. Proses identifikasi mikroorganisme menggunakan kriteria yang saling mendukung satu dengan yang lainnya sehingga dapat menentukan isolat yang diidentifikasi dan memiliki kedudukan kokoh dalam pohon filogenetik. Jika dibandingkan dengan klasifikasi tradisional (hanya berdasarkan karakter tunggal yang dipilih secara subjektif), klasifikasi fenetik lebih baik karena didasarkan atas sebanyak-banyaknya karakter yang diperlakukan setara.

\section{KESIMPULAN}

Berdasarkan hasil identifikasi yang telah dilakukan diperoleh empat isolat khamir selulolitik. Satu isolat khamir teridentifikasi sebagai Saccharomyces sp. dan tiga isolat khamir lainnya teridentifikasi sebagai Candida sp. Kemampuan mendegradasi selulosa oleh masing-masing isolat khamir 
tergantung pada media selulosa yang digunakan.

\section{DAFTAR PUSTAKA}

Abdel-Motaal FF, El-Zayat SA, Kosaka Y, El-Sayed MA, Nassar MSM and Ito S. 2009. Four Novel Ustilaginomyceteous Anamorphic Yeast Species Isolated as Endophytes from the Medicinal Plant Hyocyamus muticus. Asian Journal of Plant Science 8(8) : 526-535.

Adney B and Baker J. 2008. Measurement of Cellulase Activities: Laboratory Analytical Procedure (LAP). USA: A National Laboratory of the U.S. Department of Energy.

Chambell I. 1972. Numerycal Analysis of the Genera Saccharomyces and Kluyveromyces. Journal of General Microbiology 73: 279-301.

Fonseca A, Fell JW, Kurtzman CP and Spencer-Martin I. 2000. Candida tertarivorans sp. nov., an Anamorphic Ascomyceteous Yeast with the Capacity to Degrade L (+)- and Meso-tartaric Acid. International Journal of Systematic and Evolutionary Microbiology. 50: 389394.

Josep S. 2009. Process Optimiziation for Mass Production of Marine Yeast Candida sp. S 27 and its Nutrional Charachterization. Kochi: Chocin University of Science and Technology.

Kanti A. 2007. Penapisan Khamir Selulolitik Cryptococcus sp. yang diisolasi dari Tanah Kebun Biologi Wamena, Jaya Wijaya, Propinsi Papua. Bogor: Bidang Mikrobiologi, Puslit Biologi-LIPI: 2-10.

Kanti A dan Sudiana IM. 2002. Cellulolytic Yeast Isolated from Soil Gunung Halimun National Park. Berita Biologi. vol 6(1): 85-90.

Lasmini T dan Soetarto ES. 2014. Khamir Penghasil Indole-3-acetid acid dari Rizosfer Anggrek Tanah Pecteilis susannae (L.) Rafin. Biogenesis. vol 2(1): 56-62.

Nassar AH, El-Tarabily KA and Sivashitamparam K. 2005. Promotion
Growth by an Auxin Producing Isolate of the Yeast Wiliopsis saturnus Endophytic in Maize (Zea mays L.) roots. Biol. Fert. Soil. vol 42: 97-108.

Pfuller R, Graser Y, Erhard M, and Groene WA. 2011. Novel Flucytosine-Resistant Yeast Species, Candida pseudoaseri, Causes Diases in a Cancer Patient, Journal of Clinical Microbiology. vol. 49(12).

Qureshi SK, Masud T and Sammi S. 2007. Isolation and Taxonomic Characterization of Yeast Strains on the Basis of Maltose Utilization Capacity for Bread Making. International Journal of Agriculture \& Biology. http://www.fspublisher.org.

Samira M, Mohammad R and Gholamreza G. 2011. Carboxymethyl-Cellulase and Filter-Paperase Activity of New Stains Isolated from Persian Gulf. Microbiolgy Journal. vol 1(1): 8-16, 2011.

Sembiring L. 2004. Sistematika Mikrobia sebagai Sarana penyingkap Keanekaragaman Mikrobia dalam Upaya Pelestarian dan Pemanfaatan Sumberdaya Hayati Mikrobia. Yogyakarta: Laboratorium Mikrobiologi Fakultas Biologi UGM.

Shankar T, Mariappan V and Isaiarasu L. 2011. Screening Cellulolytic Bacteria from the Mid-Gut of the Popular Composting Earthworm Eudrilus eugeniae (Kinberg). World Journal of Zoology. vol 6 (2): 142-148.

Sneath PHA, Mair NS, Sharpe ME \& Holt JG (eds). 1986. Bergey's Manual of Systematic Bacteriology. Volume 2. William \& Wilkins. Baltimore.

Sukumaran RK, Singhania R and Pandey A. 2005. Microbial celluloses Production, application and challenges. Journal of Scienctific \& Industrial Research. vol. 62: 832-844.

Syamsudin, Purwati S dan Taufik A. 2008. Efektivitas Aplikasi Enzim Dalam Sistem Lumpur Aktif pada Pengolahan Limbah Pulp dan Kertas. Berita Selulosa. vol. 43 (2): 83-92. 